\title{
Penerapan Metode UCD (User Centered Design) pada Perancangan Aplikasi Darurat Berbasis Android
}

\author{
Muhammad lqbal ${ }^{\star 1}$, Gita Indah Marthasari ${ }^{2}$, llyas Nuryasin ${ }^{3}$ \\ 1,2,3 Teknik Informatika/Universitas Muhammadiyah Malang \\ ibal24.mi@gmail.com¹, gita.voyager@gmail.com², ilyas@umm.ac.id ${ }^{3}$
}

\begin{abstract}
Abstrak
Kasus bencana alam atau kecelakaan yang sering terjadi di Indonesia menimbulkan banyaknya nyawa korban yang melayang, hal ini dikarenakan keterlambatan dalam hal pertolongan utama, selain itu banyak dari masyarakat yang tidak tahu informasi mengenai instansi atau nomor telepon darurat yang harus dihubungi ketika dalam keadaan darurat. Kecanggihan teknologi yang semakin berkembang pesat mampu memberikan inovasi terbaru sehingga menciptakan telepon pintar (Smartphone). Salah satu bentuk pemanfaatan teknologi yang ada adalah dengan cara menciptakan sebuah aplikasi darurat untuk menangani berbagai macam kasus seperti bencana alam, kriminal, kecelakaan, dan kebakaran. Tujuan dari penelitian ini adalah menghasilkan rancangan sistem aplikasi darurat dengan metode User Centered Design (UCD) untuk menganalisa kebutuhan sistem dan desain terdiri dari fitur, tata letak, huruf, ukuran huruf, dan warna, lalu menggunakan metode Waterfall untuk implementasi sistemnya. Penelitian ini menghasilkan sebuah aplikasi darurat yang sesuai dengan kebutuhan pengguna terdiri dari fitur kondisi, panggil, berita, petunjuk arah, share facebook, login, daftar, dan edit profile, lalu untuk desain sistem pengguna memilih huruf Times New Roman, ukuran huruf sedang, serta warna biru tua, biru muda, dan putih.
\end{abstract}

Kata Kunci: Darurat, User Centered Design, Waterfall

Due to the delay of giving the first aid, the case of natural disasters and accidents that frequently happened in Indonesia cause the rise of fatalities. Besides, there are a lot of people who lack information about where and who to contact when they are in an emergency situation. Indeed, nowadays, technology is rapidly growing that it is able to provide innovations. The latest innovation that is created is the smartphone. Creating an application-that helps to handle various cases such as natural disaster, crime, accident, as well as fire-in a smartphone is one of the existing uses of technology. As for the main purpose of this research is to generate the design of the emergency application system with User-Centered Design (USD) method to analyze system needs. The design itself consists of the feature, layout, font, size of the font, and color. In addition, for system implementation, Waterfall method is used. As a final product, this research produces a useful emergency application that suits the users' needs. The application comes with many features: conditions, calls, news, directions, share to Facebook, log in, sign up, and edit profile. On the system design, the users can choose Times New Roman font, medium font size, and colors in dark blue, light blue, and white.

Keywords: Emergency, User Centered Design, Waterfall

\section{Pendahuluan}

Seperti yang diketahui penggunaan teknologi khususnya telepon genggam dari dahulu hingga sekarang berfungsi sebagai suatu alat komunikasi antar sesama, baik melalui panggilan secara langsung atau melalui pesan singkat. Kecanggihan teknologi yang semakin berkembang pesat mampu memberikan inovasi terbaru sehingga menciptakan telepon pintar (Smartphone). Telepon pintar (Smartphone) adalah sebuah aplikasi telepon yang memiliki kemampuan seperti komputer, dan disertai dengan berbagai macam fitur-fitur canggih yang ada didalamnya [1].

Android merupakan sistem operasi berbasis Linux yang dirancang untuk perangkat seluler layar sentuh seperti smartphone, dan ditulis dengan bahasa pemograman Java [2]. Sistem operasi mobile device yang sedang berkembang saat ini adalah sistem operasi mobile device yang berbasis android dan didukung oleh Google Inc, sehingg a membuat aplikasi ini 
berkembang pesat ke seluruh dunia. Aplikasi android ini memiliki sifat kode yang terbuka (Open Source), membuat banyak orang yang tertarik untuk ikut mengembangkan sistem operasi ini dan menjadikan android sebagai sistem operasi yang menawarkan banyak variasi aplikasi.

Pengembangan aplikasi telepon darurat ini dengan menerapkan metode UCD (User Centered Design), metode ini merupakan metode yang menetapkan user sebagai pusat dari perancangan sistem. Konsep dari UCD (User Centered Design) adalah user berperan sebagai pusat dari proses pengembangan sistem, sifat dan tujuan yang didasarkan dari pengalaman pengguna. Kunci utama dari keberhasilan metode ini adalah membangun sebuah kedekatan antara pengembang sistem atau programmer yang sesuai dengan keinginan pengguna [3]. Metode UCD (User Centered Design) terbukti menghasilkan perangkat lunak memiliki tingkat usability yang tinggi [4]. Menurut Sari, R. ${ }^{1}$, Utami, E. ${ }^{2}$, Amborowati, A. ${ }^{3}$, keseluruhan tahapan yang ada pada UCD (User Centered Design) terbukti dapat membuat pengguna merasa lebih nyaman dengan tampilan antarmuka yang sudah dirancang, informasi yang disajikan juga lebih mudah untuk dipahami [5].

Aplikasi ini dapat membantu pengguna ketika menghadapi keadaan darurat sehingga tidak akan terkendala untuk mencari pertolongan dengan cara mencari informasi kontak instansi yang telah tersedia pada layanan bantuan ketika sedang berada dalam keadaan darurat. Berbagai macam instansi penting jika berada dalam keadaan darurat diantaranya adalah instansi pemadam kebakaran, instansi, instansi rumah sakit, instansi polisi, dan instansi lainnya yang dapat membantu ketika seseorang berada dalam kadaan darurat.

Penelitian sebelumnya pernah dilakukan dengan judul penelitian Aplikasi Informasi Telepon Darurat Menggunakan Android Berbasis Location Based Service (LBS). Pada penelitian tersebut menjelaskan tentang pembuatan aplikasi berbasis android untuk keadaan darurat, hasil dari penelitian ini adalah pembuatan aplikasi telepeon darurat dengan cara mendeteksi otomatis, tujuannya untuk mempermudah pengguna dalam mencari informasi sesuai dengan kebutuhan dan dapat langsung menyesuaikan lokasi dari pengguna. Pengembangan aplikasi ini dengan menggunakan metode Waterfall, namun pengembangan aplikasi ini hanya sampai tahap testing. Menurut penulis masih terdapat kekurangan dalam penelitian tersebut, seperti dibutuhkannya perbaikan kinerja pelacakan lokasi, perbaikan penambahan data yang lebih baik dan dibutuhkan pengurangan kapasitas file apk karena banyaknya sumber daya yang tidak terpakai dalam aplikasi tersebut [6].

Penelitian lainnya juga yang dilakukan dengan judul Save Our Soul (SOS App). Penelitian ini menjelaskan tentang rancangan aplikasi pesan darurat yang dirancang untuk memberikan keamanan khususnya bagi para wanita dan anak-anak dengan menggunakan pelacakan lokasi melalui GPS untuk memberitahu posisi dari pengguna smartphone tersebut, dan kontak telepon darurat yang bertujuan untuk mengirimkan pesan darurat melalui pemberitahuan lewat SMS yang dikirimkan pada pengguna smartphone. Penelitian ini menghasilkan berbagai fitur, diantaranya kontak telepon darurat, Integrasi GPS, Laporan peristiwa, dan Custom push notification [7].

Penelitian lain dengan judul Rancang Bangun Website Café Tong Susu Menggunakan PHP MVC Framework dengan Metode User-Centered Design. Penelitian ini menjelaskan tentang membuat sebuah website Café Tong yang user-friendly menggunakan metode User Centered Design (UCD) dengan bahasa pemrograman PHP yang mendukung framework MVC. Hasil dari pengujian dengan kuesioner yaitu bahwa website Café Tong memiliki kesan yang baik dan kegunaan yang tinggi bagi pelanggan maupun calon pelanggan [8].

Berangkat dari beberapa penelitian terdahulu maka peneliti tertarik untuk mengambil judul penerapan metode UCD (User Centered Design) pada perancangan aplikasi darurat berbasis, tujuan menggunakan metode UCD untuk mempermudah pengguna dalam menggunakan fasilitas yang ada dalam aplikasi fitur darurat. Peneliti akan menganalisa kebutuhan fitur apa saja yang dibutuhkan pengguna dan menganalisa desain user interface yang terdiri dari tata letak, huruf, ukuran huruf, dan warna. Aplikasi android ini secara otomatis dapat diintegrasikan dengan berbagai layanan Google lainnya seperti Google Map untuk mencari alamat atau lokasi pengguna smartphone, maupun untuk memperkirakan jarak terdekat lokasi yang dicari dengan menentukan posisi pengguna smartphone koordinat dari kejadian tersebut (Location Based System).

\section{Metode Penelitian}

\subsection{Metode Waterfall}

Pengembangan aplikasi ini menggunakan metode Waterfall untuk perancangan aplikasi. Metode Waterfall (air terjun) menyediakan pendekatan alur hidup perangkat lunak secara

REPOSITOR, Vol. 2, No. 2, Februari 2020: 201-214 
sekuensial atau terurut dimulai dari analisis, desain, pengodean, pengujian dan tahap pendukung (support). Gambar 1 berikut ini model dari metode waterfall.

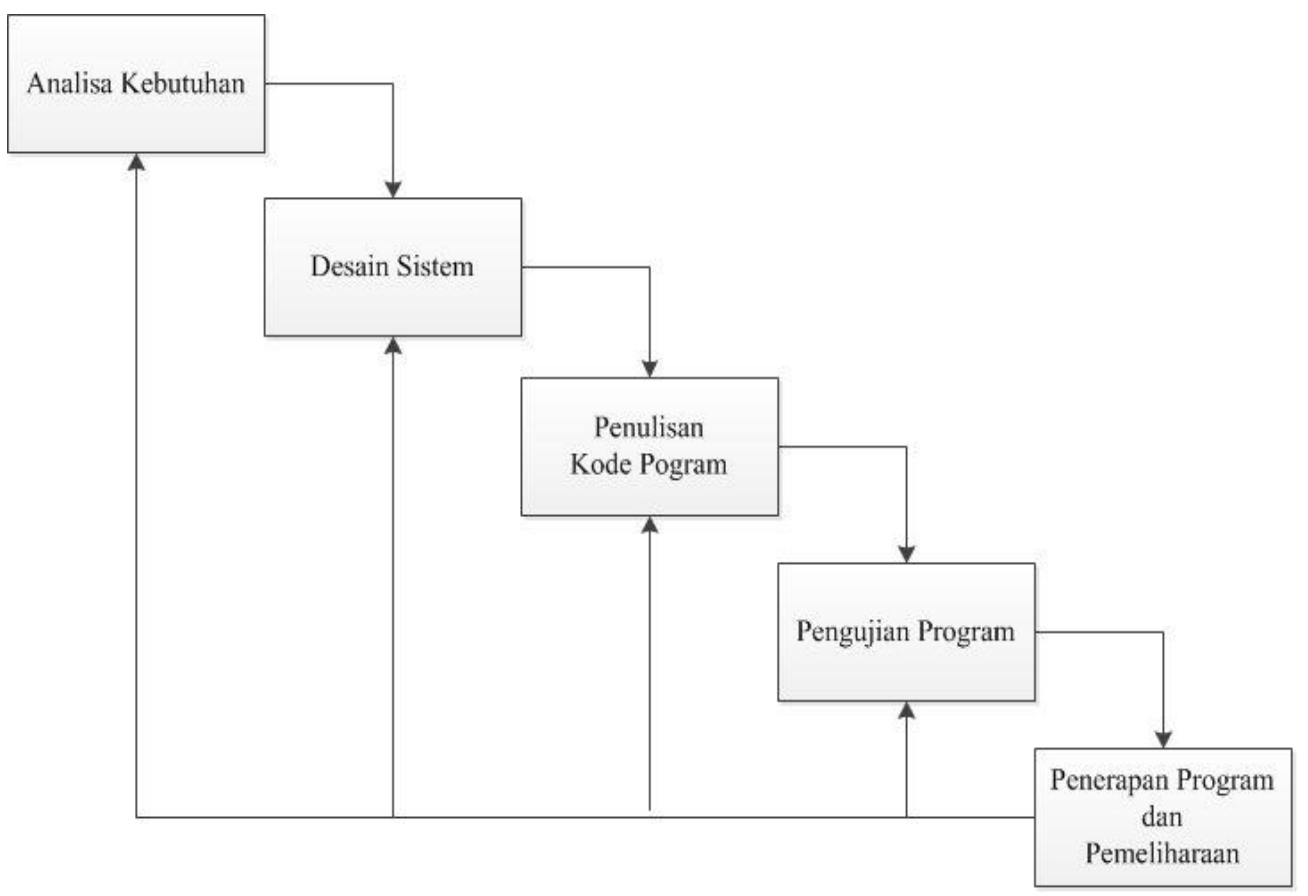

Gambar 1. Tahapan Metode Waterfall [9]

1. Analisis Kebutuhan

Proses pengumpulan kebutuhan dilakukan untuk mespesifikasikan kebutuhan perangkat lunak agar dapat dipahami perangkat lunak seperti apa yang dibutuhkan oleh user. Kebutuhan perangkat lunak pada tahap ini dilakukan pada metode User Centered Design (UCD).

2. Desain Sistem

Tahap ini mentranslasi kebutuhan perangkat lunak dari tahap analisis kebutuhan ke representasi desain agar dapat diimplementasikan menjadi program pada tahap selanjutnya. Desain perangkat lunak yang dihasilkan pada tahap ini adalah hasil dari tahapan pada metode User Centered Design (UCD).

3. Penulisan Kode Program

Desain harus ditranslasikan ke dalam program perangkat lunak. Hasil dari tahap ini adalah program komputer sesuai dengan desain yang telah dibuat pada tahap desain.

4. Pengujian Program

Pengujian fokus pada perangkat lunak memastikan bahwa semua bagian sudah diuji. Hal ini dilakukan untuk meminimalisir kesalahan (error) dan memastikan keluaran yang dihasilkan sesuai dengan yang di inginkan. Pada tahap pengujian sistem akan dilakukan dengan menggunakan Black Box.

5. Penerapan Program dan pemeliharaan (maintenance)

Tidak menutup kemungkinan sebuah perangkat lunak mengalami perubahan ketika sudah dikirimkan ke user. Perubahan bisa terjadi karena adanya kesalahan yang muncul dan tidak terdeteksi saat pengujian atau perangkat lunak harus beradaptasi dengan lingkungan baru. Tahap pendukung atau pemeliharaan dapat mengulangi proses pengembangan mulai dari analisis spesifikasi untuk perubahan perangkat lunak yang sudah ada, tapi tidak untuk membuat perangkat lunak baru [10].

\subsection{Metode User Centered Design (UCD)}

Perancangan aplikasi ini seperti pada Gambar 2, menggunakan metode UCD (User Centered Design) untuk perancangan perangkat lunak, metode UCD (User Centered Design) merupakan paradigma baru dalam pengembangan system perangkat lunak dan web. Konsep dari UCD (User Centered Design) adalah user sebagai pusat dari proses pengembangan konteks, tujuan dan lingkungan sistem berdasarkan dari pengalaman pengguna [3]. 


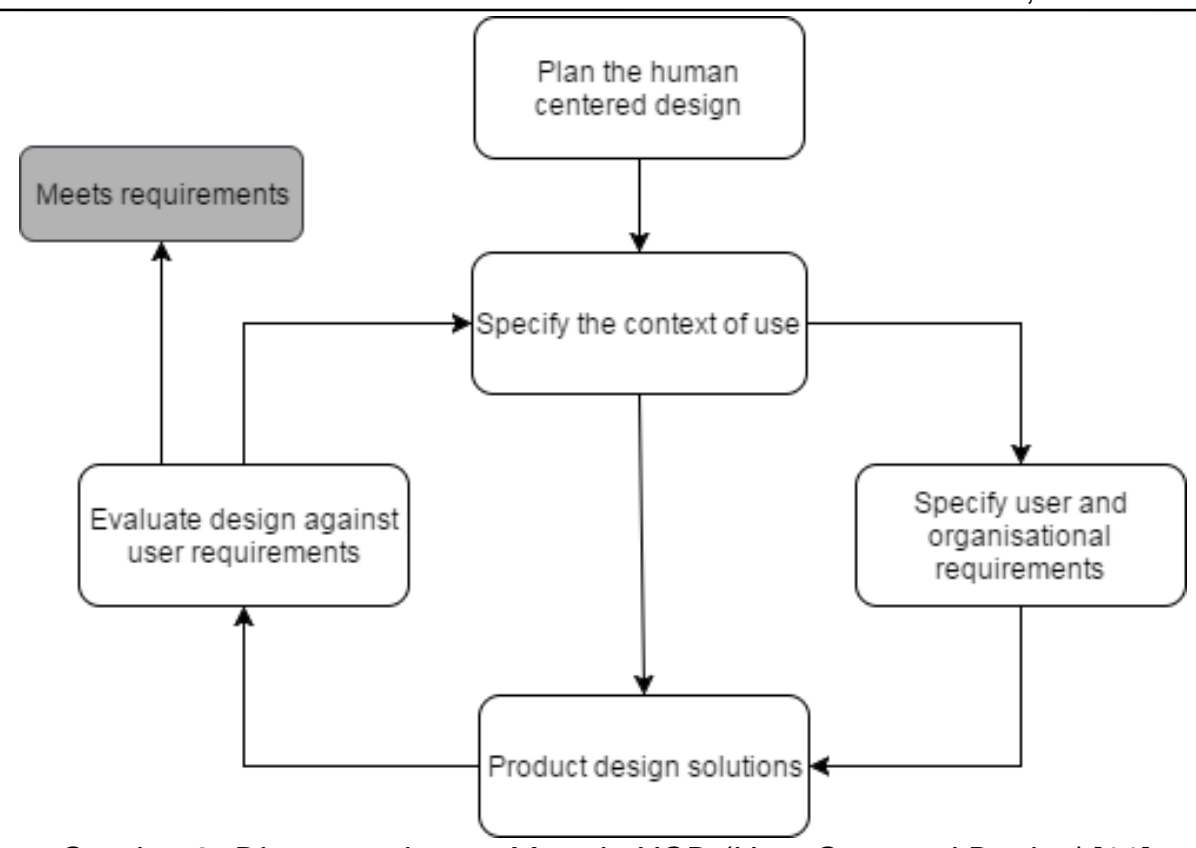

Gambar 2. Diagram tahapan Metode UCD (User Centered Design) [11]

Menurut Albani \& Lombardi (2010) pada buku User Centered Design for EASYREACH terdapat lima proses dari UCD (User Centered Design) berdasarkan ISO 9241-210:2010, yaitu: 1. Plan the human centered design

Pada tahap ini dilakukan diskusi terhadap orang-orang yang akan mengerjakan proyek, untuk mendapatkan komitmen bahwa proses pembangunan proyek adalah berpusat kepada pengguna atau user. Proyek akan memiliki waktu dan tugas untuk melibatkan pengguna atau user dalam awal dan akhir proses atau di mana mereka dibutuhkan. Hal ini untuk mempertegas bahwa perancangan suatu aplikasi sistem dengan menggunakan metode User Centered Design (UCD) dapat memenuhi keinginan dan harapan dari para pengguna.

2. Specify the context of use

Mengidentifikasi orang yang akan menggunakan produk. Ini akan menjelaskan untuk apa dan dalam kondisi seperti apa mereka akan menggunakan produk. Pada tahap ini peneliti menggunakan metode identify Stakeholders. Pengguna Aplikasi yaitu warga masyarakat yang dalam konteks keadaan darurat.

3. Specify user and organisational requirements

Pada dasarnya pada tahap ini adalah tahap penggalian informasi atau data untuk menggumpulkan kebutuhan dari pengguna, kemudian setelah informasi/data telah terkumpul, dilakukanlah penataan informasi dari data kebutuhan pengguna tersebut, lalu kebutuhan pengguna digambarkan ke dalam berbagai bentuk/teknik, seperti narasi, gambar, atau diagram, dll. Dalam Penelitian ini menggunakan kuesioner untuk menggali kebutuhan.

Di awal penelitian akan digunakan metode User Centered Design (UCD) untuk mengumpulkan data. Karena itu dilakukan aktivitas kuisioner dan wawancara yang berguna untuk mengetahui kebutuhan pengguna saat ini. Berikut beberapa pertanyaan untuk wawancara:

a. Menurut anda fitur apa saja yang perlu ditambahkan?

b. Identitas diri apa saja yang perlu dicantumkan untuk registrasi di aplikasi?

c. Apakah perlu fitur kondisi? apabila perlu, tampilan seperti apa yang anda inginkan setelah memilih menu kondisi. Berikan alasan.

Hasil dari wawancara tadi diolah ke dalam kueisoner yang di sebar melalui google formulir terhadap 50 responden. Pada hasil kuesioner setiap fitur lalu dihitung menggunakan metode skala likert didapat hasil fitur kondisi $83 \%$, fitur panggil $92 \%$, fitur petunjuk arah $92,5 \%$, fitur berita $85 \%$, fitur share Facebook $82 \%$, fitur login $73 \%$, fitur daftar $74,5 \%$, fitur edit profile $71,5 \%$.

REPOSITOR, Vol. 2, No. 2, Februari 2020: 201-214 


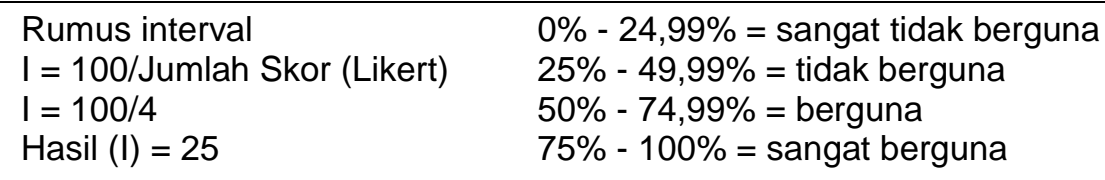

Dari hasil kuisioner dan wawancara yang telah dilakukan maka dapat ditarik beberapa kesimpulan yaitu sebagai berikut:

a. Pengguna menginginkan fitur kondisi, panggil, navigasi, berita, saran, login, daftar, dan edit profile.

b. Identitas diri yang perlu dicantumkan untuk registrasi yaitu nomor KTP, nama, password, nomor telepon, email, dan foto.

c. Desain warna setiap fitur yang ada di dalam kuesioner pengguna memilih biru tua, biru muda, dan putih.

d. Desain huruf setiap fitur yang ada di dalam kuesioner pengguna memilih opsi 1, yaitu Times New Roman.

e. Desain ukuran huruf setiap fitur yang ada di dalam kuesioner pengguna memilih sedang.

4. Product design solutions

Tahap ini merupakan tahap perancangan solusi. Dimana peneliti akan membangun desain sebagai solusi dari sistem yang sedang dianalisis. Tampilan halaman meliputi Gambar 3, Gambar 4, Gambar 5, Gambar 6, Gambar 7, dan Gambar 8.

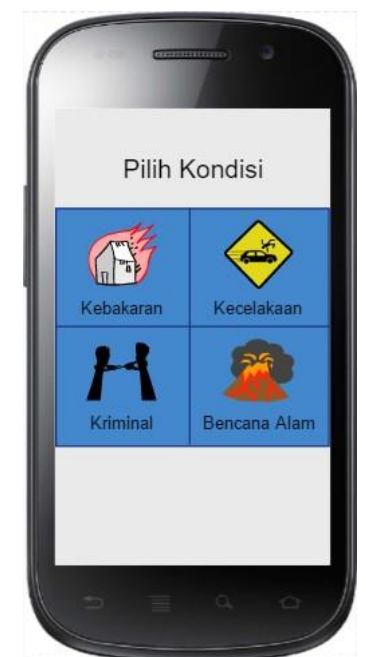

Gambar 3. Tampilan Pilih Kondisi

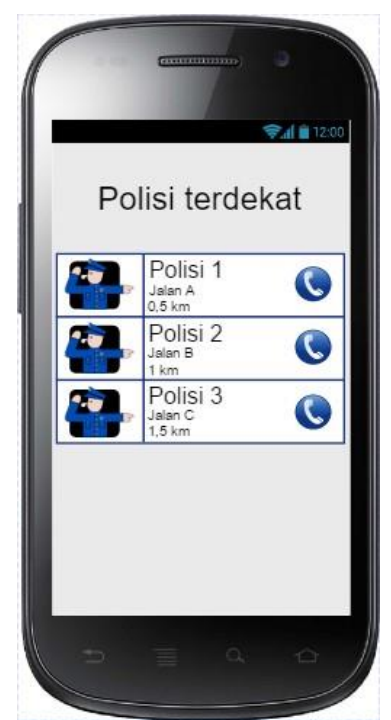

Gambar 4. Tampilan List Instansi Terdekat 


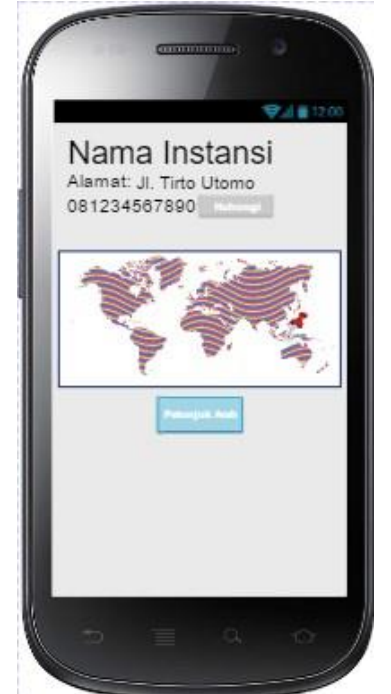

Gambar 5. Tampilan Detail Instansi

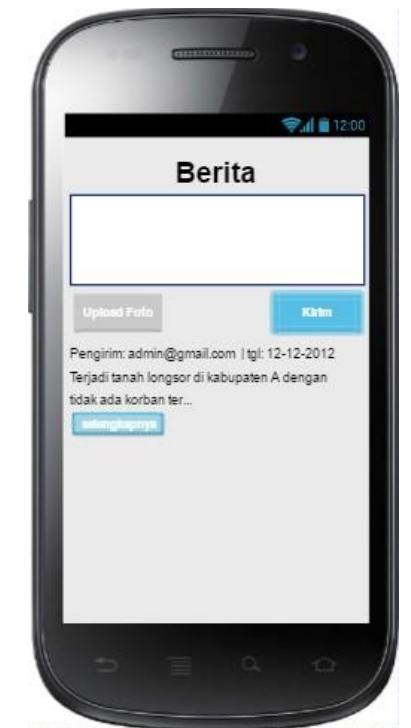

Gambar 6. Tampilan Berita

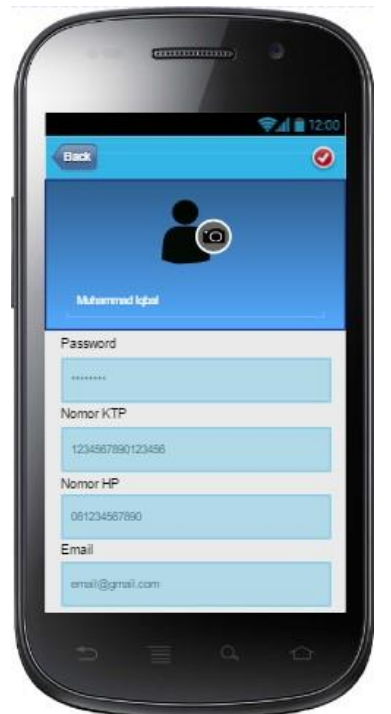

Gambar 7. Tampilan Edit Profile

REPOSITOR, Vol. 2, No. 2, Februari 2020: 201-214 


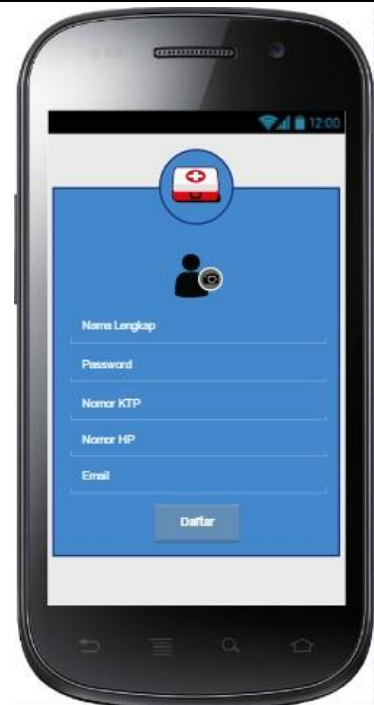

Gambar 8. Tampilan Registrasi

5. Evaluate design against user requirements

Melakukan evaluasi terhadap desain yang dilakukan apakah tujuan pengguna dan organisasi telah tercapai [11]. Tahapan ini merupakan kelanjutan dari solusi perancangan dimana hasil solusi yang didapat dari tahap solusi perancangan dapat dievaluasi dan diambil kesimpulan tentang kebutuhan pengguna terhadap fitur yang akan ditambahkan pada fitur darurat yang dibangun. Fitur-fitur tersebut adalah kondisi, panggil, navigasi, berita, share Facebook, login, daftar, dan edit profile. Berikut evaluasi kegunaan fitur yang dikembangkan pada aplikasi fitur darurat terhadap kebutuhan pengguna:

a. Untuk mempermudah pengguna dalam menentukan kejadian darurat, aplikasi fitur darurat menghadirkan fitur kondisi untuk menentukan kondisi daruratnya dan fitur lokasi untuk menentukan intansi yang terdekat dengan pengguna lalu menghubungi instansi terkait dengan fitur panggil.

b. Untuk mengetahui tempat instansi, aplikasi fitur darurat menghadirkan fitur navigasi untuk menuntun pengguna ke tempat instansi yang dituju.

c. Untuk mengetahui tempat lokasi kejadian dan bagaimana situasi kejadian, aplikasi fitur darurat menghadirkan fitur berita yang berfungsi mengetahui berita keadaan darurat yang disekitar pengguna dengan mengirim titik lokasi kejadian serta fitur foto untuk menunjukan situasi kejadian diposisi pengguna.

d. Untuk dapat menggunakan aplikasi ini pengguna diharuskan registrasi dengan fitur daftar serta untuk masuk ke dalam aplikasinya pengguna diharuskan sudah registrasi dan mengisi username dan password untuk fitur login dan pengguna juga dapat merubah profile dengan adanya fitur edit profile.

\section{Hasil Penelitian dan Pembahasan}

\subsection{Implementasi Sistem}

Implementasi Interface halaman user merupakan implementasi halaman utama yang digunakan oleh user sebagai pengguna aplikasi yang berisi informasi-informasi tentang aplikasi fitur darurat.

\subsection{1 tampilan Halaman Login}

Halaman login merupakan halaman utama dari Aplikasi fitur darurat. Halaman ini berfungsi sebagai tempat untuk menampilkan form login. Adapun Tampilan form login pada Gambar 9.

Gambar 9 di bawah merupakan gambar halaman registrasi ketika tombol registrasi di klik, halaman registrasi akan menampilkan inputan data diri dan tombol registrasi untuk menyimpan registrasi ke dalam database. 


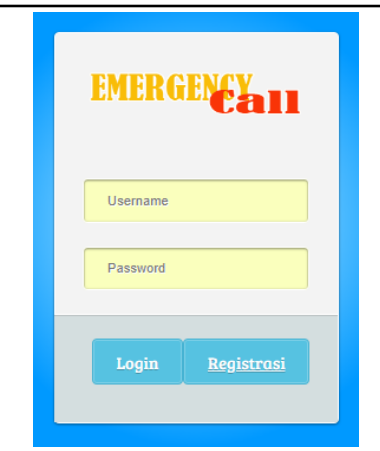

Gambar 9. Tampilan Login

\subsubsection{Tampilan Halaman Registrasi}

Halaman registrasi merupakan halaman yang berfungsi sebagai tempat untuk menginputkan data diri sebagai member aplikasi. Adapun Tampilan form registrasi sebagai berikut.

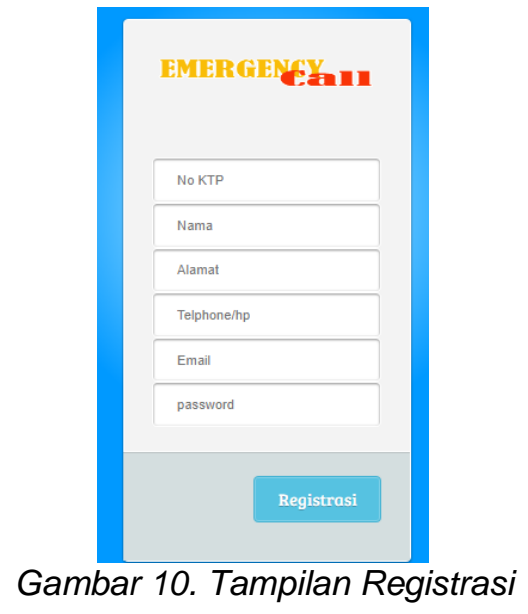

Gambar 10 diatas merupakan gambar halaman login ketika aplikasi pertama kali di jalanakan, halaman login akan menampilkan inputan username dan password dan tombol login selain tombol login juga terdapat tombol registrasi.

\subsubsection{Tampilan Halaman Utama}

Halaman Utama merupakan halaman beranda dari Aplikasi Fitur Darurat. Halaman ini berfungsi sebagai tempat untuk menampilkan informasi-informasi tentang menu Aplikasi. Adapun Tampilan Utama sebagai berikut.

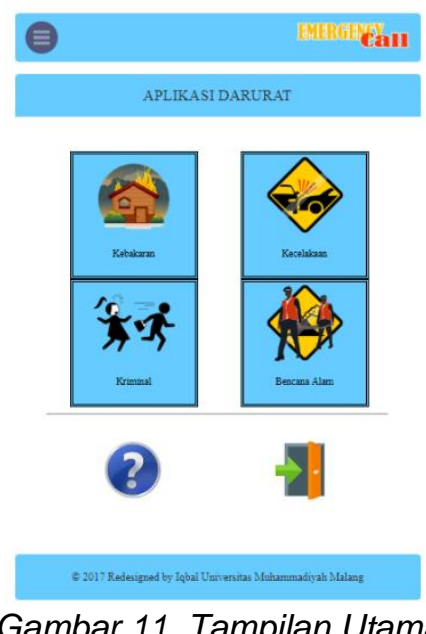

Gambar 11. Tampilan Utama

REPOSITOR, Vol. 2, No. 2, Februari 2020: 201-214 
Gambar 11 diatas merupakan gambar halaman utama ketika aplikasi pertamakali di jalanakan, halaman utama akan menampilkan beberapa tombol yaitu tombol menu yang terdapat pada pojok kiri atas yang berfungsi untuk menampilkan menu slide dari aplikasi, Gambar 12 berikut adalah gambar tampilan jika tombol menu di klik.

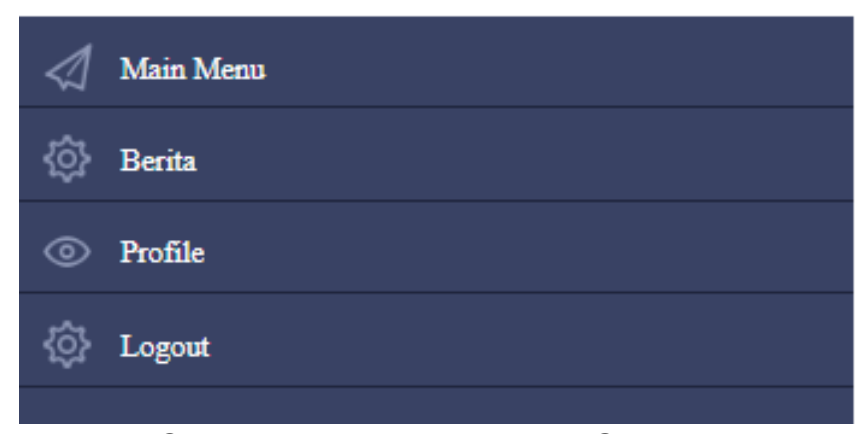

Gambar 12. Tampilan Menu Samping

Tombol menu merupakan tombol dinamis untuk menampilkan detail menu dan setiap menu memiliki fungsi masing-masing yaitu main menu berfungsi untuk menampilkan halaman utama, menu profile berfungsi untuk menampilkan profile pengguna, menu berita untuk menampilkan daftar berita emergency, sedangkan logout berfungsi untuk keluar dari aplikasi.

\subsubsection{Tampilan Halaman Daftar Instansi}

Halaman daftar unit darurat berfungsi untuk menampilkan daftar unit darurat yang sudah tersimpan pada database. Tampilan halaman daftar unit darurat dapat dilihat pada Gambar 13.

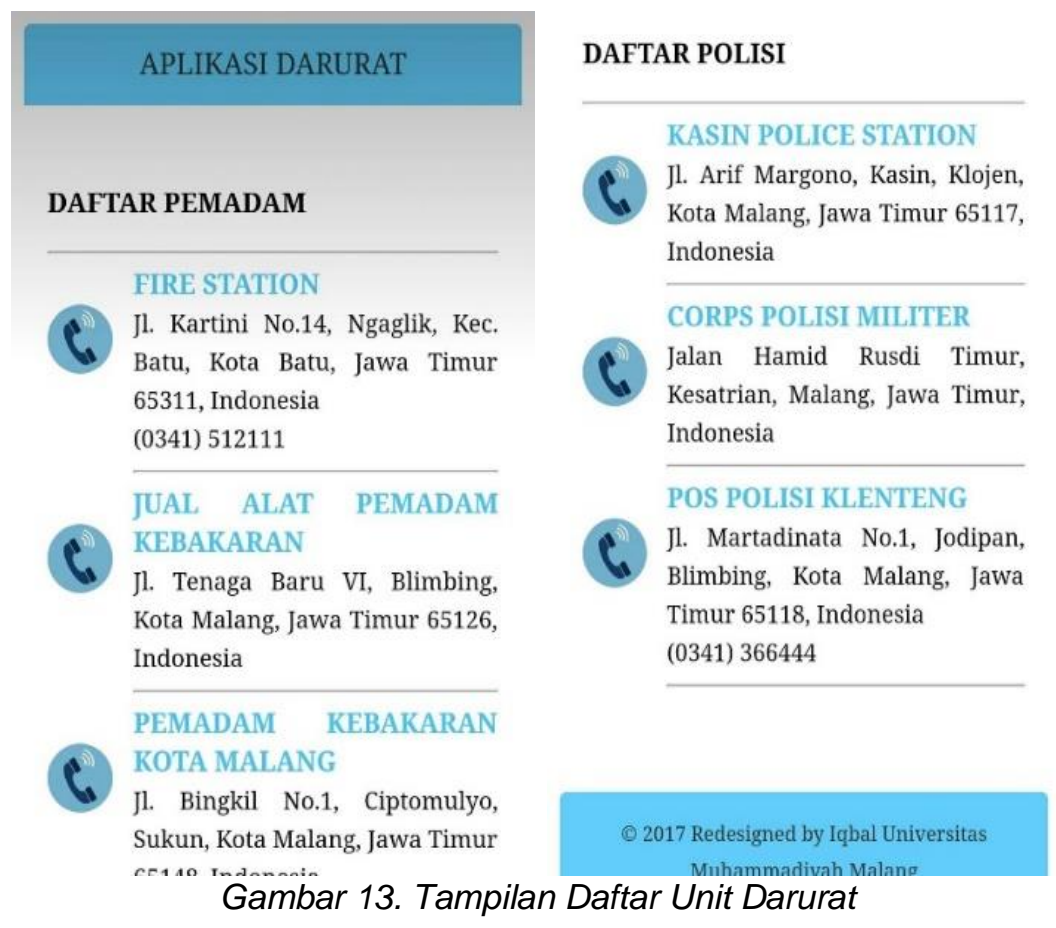

Pada gambar halaman unit darurat diatas terdapat tombol panggil yang berfungsi untuk menghubungi unit darurat.

\subsubsection{Tampilan Halaman Detail Instansi}

Halaman detail unit instansi merupakan halaman yang berfungsi untuk menampilkan data detail dari unit instansi. Gambar 14 berikut merupakan tampilan dari halaman detail unit instansi. 


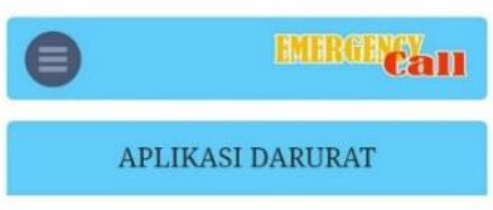

\section{FIRE STATION}

Alamat : Jl. Kartini No.14, Ngaglik, Kec.

Batu, Kota Batu, Jawa Timur 65311,

Indonesia

Telp : (0341) 512111 Hubungi

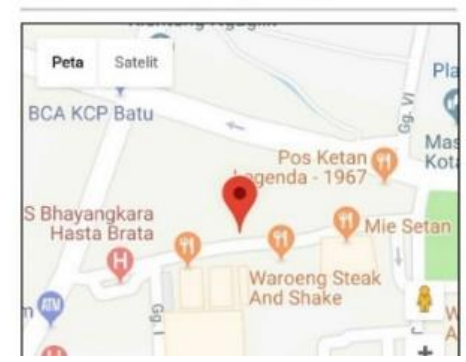

Gambar 14. Tampilan Detail Instansi

\subsubsection{Tampilan Halaman Berita}

Halaman Berita merupakan halaman yang berfungsi untuk menampilkan data berita pesan keadaan darurat, sehingga pengguna dapat melihat daftar lokasi yang sedang terjadi kondisi darurat Form berita merupakan form yang dapat di isi oleh pengguna untuk menginformasi tempat yang sedang gangguan atau tidak aman. Gambar 15 berikut merupakan implementasi dari halaman form kirim pesan dan halaman daftar berita.
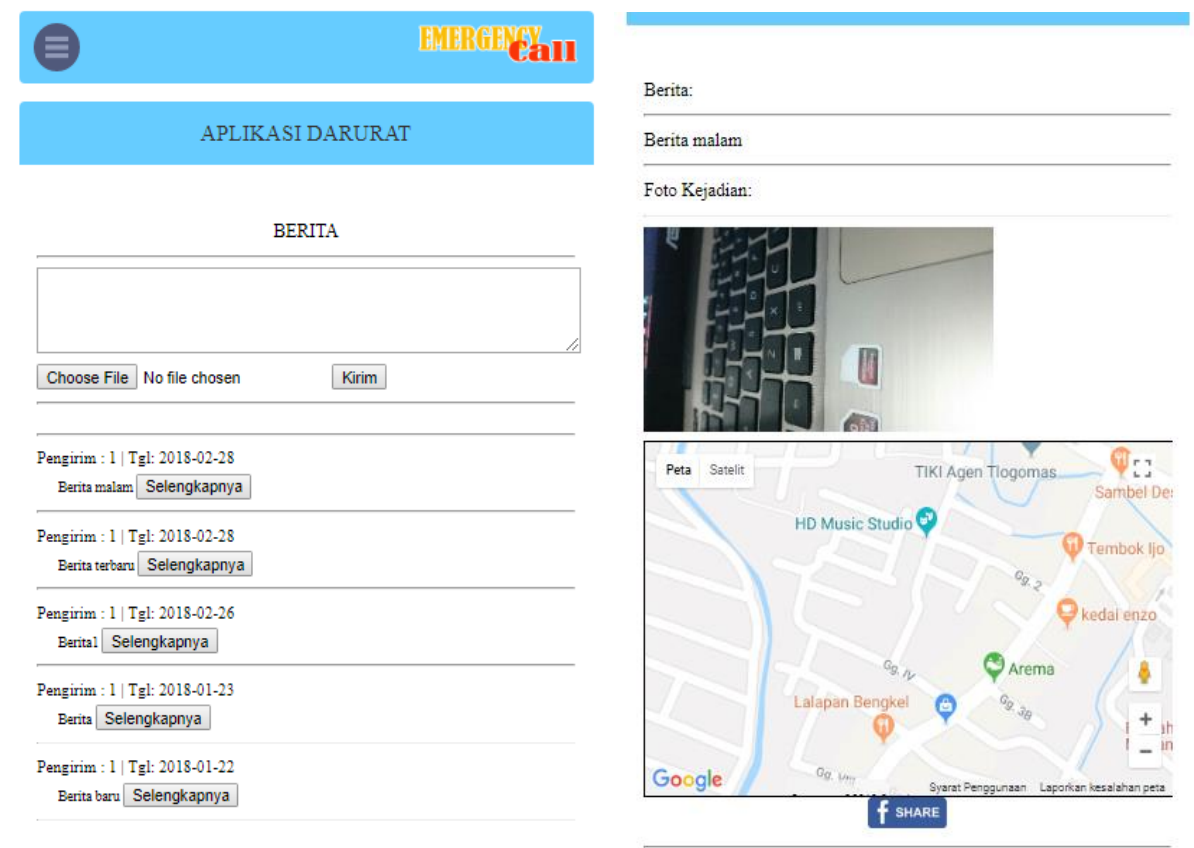

Gambar 15. Tampilan Berita

\subsubsection{Tampilan Halaman Profile Pengguna}

Halaman profile merupakan halaman yang bagi user yang ingin melihat data profile dan juga untuk merubah data profile. Gambar 16 berikut merupakan implementasi tampilan halaman prifile. 


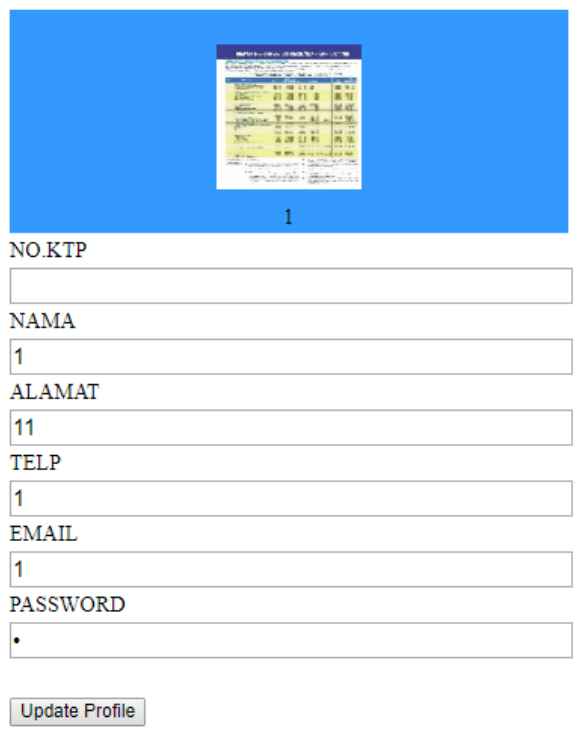

Gambar 16. Tampilan Menu Profile

\title{
3.1.8. Tampilan Halaman About
}

Halaman about merupakan halaman yang berfungsi untuk menampilkan tentang aplikasi, dan pembuatnya. Gambar 17 berikut merupakan tampilan halaman about.

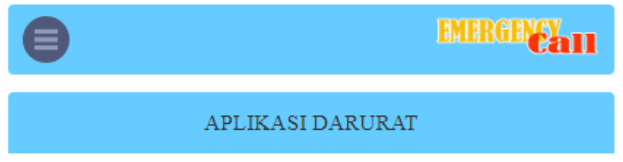

\section{EMERGiVEUII}

\author{
Apliasi Fitur Darurat \\ Berbasis Android \\ Versi Beta 1.0 \\ Developed By Iqbal \\ Universitas muhammadiyah malang
}

Gambar 17. Tampilan Halaman About

\subsection{Pengujian Menggunakan Black Box}

Setelah dilakukan rancangan maka berikut adalah hasil dari pengujiannya, pengujian sistem yang digunakan adalah pengujian blackbox atau pengujian fungsioanal sistem yang ditampilkan pada Tabel 1.

Berdasarkan hasil pengujian dengan menggunakan butir uji diatas, aplikasi ini dapat berjalan dengan baik secara fungsional sistem dan dapat menghasilkan output yang diharapkan. 
Tabel 1. Pengujian Black Box Aplikasi

\begin{tabular}{|c|c|c|c|}
\hline \multicolumn{4}{|c|}{ Kasus dan Hasil Uji (data normal) } \\
\hline Deskripsi & Yang diharapkan & pengamatan & Kesimpulan \\
\hline $\begin{array}{l}\text { Load halaman } \\
\text { Utama }\end{array}$ & $\begin{array}{c}\text { Menampilkan Halaman } \\
\text { utama }\end{array}$ & $\begin{array}{l}\text { Dapat Menampilkan halaman } \\
\text { utama dengan benar }\end{array}$ & $\begin{array}{l}{[\checkmark] \text { diterima }} \\
{[\quad] \text { ditolak }}\end{array}$ \\
\hline $\begin{array}{l}\text { Tombol menu } \\
\text { registrasi }\end{array}$ & $\begin{array}{l}\text { Menampilkan form } \\
\text { registrasi aplikasi }\end{array}$ & $\begin{array}{l}\text { Dapat Menampilkan form } \\
\text { registrasi aplikasi }\end{array}$ & $\begin{array}{l}{[\sqrt{ }] \text { diterima }} \\
{[\quad] \text { ditolak }}\end{array}$ \\
\hline Form Registrasi & $\begin{array}{l}\text { Menampilkan form } \\
\text { registrasi dan daftar } \\
\text { registrasi dan dapat } \\
\text { melakukan simpan data }\end{array}$ & $\begin{array}{c}\text { Dapat Menampilkan form } \\
\text { registrasi dan daftar registrasi } \\
\text { dan dapat melakukan simpan } \\
\text { data registrasi }\end{array}$ & $\begin{array}{l}{[\checkmark] \text { diterima }} \\
{[\quad] \text { ditolak }}\end{array}$ \\
\hline Tombol login & Menampilkan form login & $\begin{array}{c}\text { Dapat Menampilkan form } \\
\text { login dan mevalidasi login } \\
\text { user }\end{array}$ & $\begin{array}{l}{[\checkmark] \text { diterima }} \\
{[\quad] \text { ditolak }}\end{array}$ \\
\hline $\begin{array}{l}\text { Tombol main } \\
\text { menu }\end{array}$ & $\begin{array}{c}\text { Menampilkan menu utama } \\
\text { aplikasi }\end{array}$ & $\begin{array}{c}\text { Dapat Menampilkan menu } \\
\text { utama aplikasi }\end{array}$ & $\begin{array}{l}{[\sqrt{ }] \text { diterima }} \\
{[\quad] \text { ditolak }}\end{array}$ \\
\hline $\begin{array}{l}\text { Tombol menu } \\
\text { kondisi }\end{array}$ & $\begin{array}{l}\text { Menampilkan daftar } \\
\text { instansi terdekat yang } \\
\text { berkaitan }\end{array}$ & $\begin{array}{l}\text { Dapat menampilkan daftar } \\
\text { instansi yang berkaitan }\end{array}$ & $\begin{array}{l}{[\sqrt{ }] \text { diterima }} \\
{[\quad] \text { ditolak }}\end{array}$ \\
\hline Ikon telepon & $\begin{array}{l}\text { Mengarahkan ke } \\
\text { panggilan }\end{array}$ & $\begin{array}{l}\text { Dapat mengarahkan ke } \\
\text { panggilan }\end{array}$ & $\begin{array}{l}{[\checkmark] \text { diterima }} \\
{[] \text { ditolak }}\end{array}$ \\
\hline $\begin{array}{l}\text { Daftar instansi } \\
\text { terdekat }\end{array}$ & $\begin{array}{c}\text { Menampilkan detail } \\
\text { instansi }\end{array}$ & $\begin{array}{c}\text { Dapat menampilkan detail } \\
\text { instansi }\end{array}$ & $\begin{array}{l}{[\checkmark] \text { diterima }} \\
{[\quad] \text { ditolak }}\end{array}$ \\
\hline $\begin{array}{l}\text { Tombol menu } \\
\text { hubungi }\end{array}$ & $\begin{array}{l}\text { Mengarahkan ke } \\
\text { panggilan }\end{array}$ & $\begin{array}{l}\text { Dapat mengarahkan ke } \\
\text { panggilan }\end{array}$ & $\begin{array}{l}{[\sqrt{ }] \text { diterima }} \\
{[\quad] \text { ditolak }}\end{array}$ \\
\hline $\begin{array}{l}\text { Tombol menu } \\
\text { petunjuk arah }\end{array}$ & $\begin{array}{c}\text { Mengarahkan ke aplikasi } \\
\text { peta untuk petunjuk arah } \\
\text { ke instansi }\end{array}$ & $\begin{array}{l}\text { Dapat mengarahkan ke } \\
\text { aplikasi peta untuk petunjuk } \\
\text { arah ke instansi }\end{array}$ & $\begin{array}{l}{[\checkmark] \text { diterima }} \\
{[\quad] \text { ditolak }}\end{array}$ \\
\hline $\begin{array}{l}\text { Tombol menu } \\
\text { Profile }\end{array}$ & $\begin{array}{l}\text { Menampilkan Profile } \\
\text { pengguna }\end{array}$ & $\begin{array}{l}\text { Dapat Menampilkan profile } \\
\text { pengguna }\end{array}$ & $\begin{array}{l}{[\checkmark] \text { diterima }} \\
{[\text { ] ditolak }}\end{array}$ \\
\hline $\begin{array}{l}\text { Tombol update } \\
\text { Profile }\end{array}$ & $\begin{array}{l}\text { Memperbarui data Profile } \\
\text { pengguna }\end{array}$ & $\begin{array}{l}\text { Dapat Memperbarui data } \\
\text { Profile pengguna }\end{array}$ & $\begin{array}{l}{[\sqrt{ }] \text { diterima }} \\
{[\quad] \text { ditolak }}\end{array}$ \\
\hline Tombol Berita & $\begin{array}{l}\text { Menampilkan daftar berita } \\
\text { dan form berita }\end{array}$ & $\begin{array}{l}\text { Dapat Menampilkan daftar } \\
\text { berita dan form berita }\end{array}$ & $\begin{array}{l}{[\checkmark] \text { diterima }} \\
{[] \text { ditolak }}\end{array}$ \\
\hline Form berita & Menulis berita & Dapat menulis berita & \\
\hline Tombol pilih file & $\begin{array}{l}\text { Mengarahkan ke aplikasi } \\
\text { kamera }\end{array}$ & $\begin{array}{c}\text { Dapat mengarahkan ke } \\
\text { aplikasi kamera }\end{array}$ & $\begin{array}{l}{[\vee] \text { diterima }} \\
{[\quad] \text { ditolak }}\end{array}$ \\
\hline Ambil Koordinat & $\begin{array}{l}\text { Mengambil titik koordinat } \\
\text { GPS yaitu latitude dan } \\
\text { longitude }\end{array}$ & $\begin{array}{c}\text { Dapat Mengambil titik } \\
\text { koordinat GPS yaitu latitude } \\
\text { dan longitude }\end{array}$ & $\begin{array}{l}{[\sqrt{ }] \text { diterima }} \\
{[\quad] \text { ditolak }}\end{array}$ \\
\hline Tombol kirim & Mengirim berita kejadian & $\begin{array}{c}\text { Dapat mengirim berita } \\
\text { kejadian }\end{array}$ & $\begin{array}{l}{[\sqrt{ }] \text { diterima }} \\
{[\quad] \text { ditolak }}\end{array}$ \\
\hline $\begin{array}{c}\text { Tombol } \\
\text { selengkapnya }\end{array}$ & Menampilkan detail berita & $\begin{array}{c}\text { Dapat menampilkan detail } \\
\text { berita }\end{array}$ & $\begin{array}{l}{[\vee] \text { diterima }} \\
{[\quad] \text { ditolak }}\end{array}$ \\
\hline Tombol about & Menampilkan info aplikasi & $\begin{array}{c}\text { Dapat Menampilkan info } \\
\text { aplikasi }\end{array}$ & $\begin{array}{l}{[\vee] \text { diterima }} \\
{[\quad] \text { ditolak }}\end{array}$ \\
\hline Tombol keluar & $\begin{array}{c}\text { Keluar dari aplikasi fitur } \\
\text { darurat }\end{array}$ & $\begin{array}{c}\text { Dapat keluar dari aplikasi fitur } \\
\text { darurat }\end{array}$ & $\begin{array}{l}{[\vee] \text { diterima }} \\
{[\quad] \text { ditolak }}\end{array}$ \\
\hline $\begin{array}{c}\text { Tombol menu } \\
\text { logout }\end{array}$ & $\begin{array}{l}\text { Mengeluarkan aplikasi } \\
\text { dari sesi login }\end{array}$ & $\begin{array}{l}\text { Dapat Mengeluarkan aplikasi } \\
\text { dari sesi login }\end{array}$ & $\begin{array}{l}{[\checkmark] \text { diterima }} \\
{[\quad] \text { ditolak }}\end{array}$ \\
\hline
\end{tabular}

REPOSITOR, Vol. 2, No. 2, Februari 2020: 201-214 


\section{Kesimpulan \\ 4.1 Kesimpulan}

Setelah melalui proses pembangunan dan pengujian aplikasi fitur darurat berbasis android dapat diambil kesimpulan sebagai berikut:

1. Tersedia pengiriman pesan darurat secara online melalui aplikasi android.

2. Metode User centered Design (UCD) dapat memberikan kontribusi dalam proses perancangan sesuai dengan kebutuhan pengguna yang terdiri dari tata letak, huruf Times New Roman, ukuran huruf sedang, dan warna meliputi biru tua, biru muda, dan putih pada tahap analisa dan desain di metode Waterfall.

3. Hasil pengujian dengan menggunakan butir uji pada bab sebelumnya, aplikasi ini dapat berjalan dengan baik secara fungsional sistem dan dapat menghasilkan output yang diharapkan.

\subsection{Saran}

Aplikasi fitur darurat berbasis android masih terdapat beberapa kekurangan, berikut merupakan saran untuk mendapatkan aplikasi yang lebih sempurna dan tampilan aplikasi perlu dikembangkan agar dapat berjalan di beberapa perangkat mobile lainnya seperti perangkat IOS dan Windows Phone.

\section{Referensi}

[1] B. Williams dan S. C. Sawyer, Using Information Technology: A Practical Introduction to Computers \& Communications. (9th edition), New York: McGraw-Hill, 2011.

[2] N. S. H, Android Pemrograman Aplikasi Mobile Smartphone dan Tablet PC Berbasis Android, Bandung: Informatika, 2011.

[3] Legianto, "Perancangan Katalog Produk Berbasis Web Menggunakan Metode User Centered Design Pada Cv. Creative Bah Adzka Grafika," Pelita Informatika Budi Darma, vol. VIII, no. 3, pp. 129-133, 2014.

[4] H. A. Fatta, analisis dan perancangan sistem informasi untuk keunggulan bersaing perusahaan dan organisasi modern, Yogyakarta: Penerbit Andi, 2007.

[6] E. Retnoningsih, "Aplikasi informasi telepon darurat menggunakan android berbasis location Based service (LBS)," dalam Seminar Nasional Sains dan Teknologi, Jakarta, 2016.

[5] R. Sari, E. Utami dan A. Amborowati, "Rancangan Lowongan Kerja Online Menggunakan Metode User Centered Design (Studi Kasus: Business Placement Center STMIK AMIKOM Yogyakarta)," Citec Journal, vol. III, no. 1, pp. 62-73, 2016.

[7] S. Rai, Z. Shikalgar, A. Agarwal, A. Rathod, M. Gangawane dan Pallavi, "Save Our Soul (SOS App)," Imperial Journal of Interdisciplinary Research (IJIR), vol. II, no. 5, pp. 158-163, 2016.

[8] A. H. Wulandari, S. P. Arifin and I. Muslim, "Rancang Bangun Website Café Tong Susu Menggunakan PHP MVC Framework dengan Metode User-Centered Design," Jurnal Aksara Komputer Terapan Politeknik Caltex Riau, vol. V, no. 1, pp. 40-46, 2016.

[9] R. Taufiq and I. S. Mustofa, "Perancangan Sistem Pendukung Keputusan Kejurusan Menggunakan Metode Simple Additive Weighting (SAW) Di Sma Negeri 15 Tangerang," TI Atma Luhur, vol. IV, no. 1, pp. 103-114, 2017.

[10] S. Susilowati, "Pengembangan Sistem Informasi Manajemen Zakat, Infaq, Shadaqoh, Waqaf dan Hibah Menggunakan Metode Waterfall," Paradigma, vol. XIX, no. 1, pp. 52-60, 2017.

[11] L. Albani and G. Lombardi (FIMI), User Centred Design for Easyreach, 2010. 
REPOSITOR, Vol. 2, No. 2, Februari 2020: 201-214 